\title{
Movements and Habitat Use by Temperate-Nesting Canada Geese During the Postbreeding Period in Southern Québec
}

\section{Déplacements et utilisation de l'habitat par la Bernache du Canada résidente en période post-reproductive dans le sud du Québec}

\author{
Matthieu Beaumont $^{1}$, Jean Rodrigue ${ }^{2}$ and Jean-Francois Giroux ${ }^{1}$
}

\begin{abstract}
Individual behavior that reduces vulnerability to predation can affect population dynamics of animals. Temperatenesting Canada Geese (Branta canadensis maxima) have increased steadily throughout the Atlantic flyway and have become a nuisance in some parts of their range. The objective of our study was to describe movements and habitat use during the postbreeding period of Canada Geese recently established in southern Québec. More specifically, we wanted to determine whether geese were using areas where hunting was allowed to assess the potential of harvest to control the number of geese. We tracked a sample of geese fitted with radio or conventional alphanumeric collars throughout the fall in three zones characterized by different habitats and hunting pressure. Before the hunting season, geese left the breeding area where hunting was allowed to reach suburban areas where firearm discharge was prohibited or hunters' numbers were low. These postbreeding movements occurred when juveniles were approximately three months old. We observed few local movements among zones once migrant geese from northern breeding populations reached the study area. Radio-collared geese used mainly natural habitats $(75.4 \pm 2.6 \%)$, followed by urban $(14.4 \pm 2.7 \%)$, and agricultural habitats $(10.3 \pm 0.8 \%)$. They were located $73.8 \pm 6.2 \%$ of the time in areas where hunting was prohibited. Geese that attended their juveniles during brood rearing were more prone to use areas where firearm discharge was restricted than geese that had abandoned or lost their brood. This study shows that under the prevailing regulations, the potential of hunting to manage the increasing breeding population of Canada Geese in southern Québec is limited.
\end{abstract}

RÉSUMÉ. Le comportement que les individus adoptent pour réduire leur vulnérabilité face à la prédation peut affecter la dynamique des populations. La population résidente de Bernaches du Canada (Branta canadensis maxima) a considérablement augmenté dans le corridor de migration de l'Atlantique, à un point tel qu'elles sont devenues nuisibles à certains endroits. L'objectif de notre étude était de décrire les déplacements et l'utilisation des milieux durant la période post-reproductive des Bernaches du Canada récemment établies dans le sud du Québec. Afin d'évaluer le potentiel de la chasse pour contrôler le nombre de bernaches, nous voulions déterminer si les bernaches utilisaient les zones dans lesquelles la chasse est permise. Au cours de l'automne, nous avons suivi des bernaches munies d'un collier avec émetteur ou d'un collier conventionnel alphanumérique dans trois zones caractérisées par différents habitats et pressions de chasse. Bien avant l'ouverture de la chasse, les bernaches ont délaissé le secteur où elles avaient niché et qui était accessible aux chasseurs pour se déplacer vers des sites périurbains où les chasseurs étaient peu nombreux ou encore absents en raison de l'interdiction de décharger des armes à feu. Ces déplacements post-reproductifs se sont effectués lorsque les jeunes étaient âgés de trois mois environ. Nous avons observé peu de déplacements entre les zones une fois que les Bernaches du Canada migratrices en provenance du nord furent arrivées. Les bernaches munies d'émetteurs ont surtout utilisé des habitats naturels $(75,4 \pm 2,6 \%)$, des milieux urbains $(14,4 \pm 2,7 \%)$ et des terres agricoles $(10,3 \pm 0,8 \%)$. Elles ont été localisées 73,8 $\pm 6,2 \%$ du temps dans les territoires où la chasse était interdite. Les bernaches qui étaient accompagnées de leurs jeunes durant l'élevage ont passé davantage de temps dans des zones sans chasse que celles qui avaient perdu ou abandonné leurs jeunes. Cette étude montre que le rôle potentiel de la chasse pour gérer la population de Bernaches du Canada, en expansion dans le sud du Québec, est limité considérant la réglementation en vigueur.

Key Words: Branta canadensis maxima; Canada Goose; habitat use; hunting disturbance; movement; Québec; suburb ecology 


\section{INTRODUCTION}

The choice of foraging habitats by animals is assumed to be an active process with the goal of maximizing their net rate of energy intake (Stephens and Krebs 1986). Individuals face trade-offs between predation risks and foraging opportunities (Lima and Dill 1990). They should thus adopt optimal strategies that maintain energy balance and reduce probability of mortality. Mobile animals like birds have the option of moving to a more favorable environment when foraging costs become greater than gains (Frederick and Klaas 1982). During the postbreeding period, migratory birds must complete their growth and/or accumulate reserves for their fall migration. For game species, movements of individuals in response to hunting may influence survival and be a leading feature in population dynamics (Madsen and Fox 1995). They should therefore use habitats that provide access to food and at the same time minimize encounters with hunters. The presence of refuges where the birds can rest or forage without being disturbed may influence their distribution and local movements (Madsen 1998).

Over the past 40 years, waterfowl managers have favored hunting to regulate the growth of several goose populations in North America (Ankney 1996, Johnson 1997). Reduction of adult survival through increased harvest appears to be the most influential controlling measure (Gauthier and Brault 1998). In the Atlantic flyway, the demographic expansion of temperatenesting Canada Geese (Branta canadensis maxima, TNCG) has been recently stabilized, in part because of higher harvest resulting from special hunting seasons in several states and provinces (Heusmann 1999, Hindman et al. 2004, U.S. Fish and Wildlife Service 2010). However, the ability of this species to exploit urban environments may prevent achievement of management goals because hunting activities are often prohibited or restricted around cities (Conover and Chasko 1985, Ankney 1996, Balkcom 2010).

TNCG have expanded their range in northeastern America and are now breeding in southern Quebec where the population is rapidly growing (Giroux et al. 2001). The area is characterized by urban, suburban, and rural settings with diverse habitats and different hunting regulations. In this study, we took advantage of the spatiotemporal variation in hunting activity and the availability of different habitats to determine how these factors affect the postbreeding distribution and local movements of TNCG established near Montréal. More specifically, we wanted to determine whether geese were using areas where hunting was allowed to assess the potential of harvest to control the number of geese.

\section{METHODS}

\section{Study area}

The study area encompassed $417 \mathrm{~km}^{2}$ within the Communauté métropolitaine de Montréal, including $97 \mathrm{~km}^{2}$ of unsuitable goose habitats such as roads, hardscape, and woodlots that were excluded (Fig. 1). We divided the area into three zones according to hunting activity and land use. The east zone (192 $\mathrm{km}^{2}$ ) included the nesting, rearing, and molting sites of Canada Geese that breed at Varennes (Giroux et al. 2001). The surrounding mainland, especially along the south shore of the Saint-Lawrence River, was mainly covered by agricultural lands dominated by small grain cereals and cornfields, the latter being used for livestock feeding. Except for the urban portions of Montréal, Répentigny, Varennes, and Boucherville, waterfowl hunting was allowed in over $99 \%$ of the zone and started on the fourth Saturday of September until mid-December. A special early goose season that began on 6 September was established in 2003 and was limited to agricultural lands. The Saint-Lawrence Seaway passes through the zone, and there can be substantial boating activities during the summer and fall.

Fig. 1. Location of the west, central, and east zones where Canada Geese (Branta canadensis maxima) were surveyed and tracked in 2004 near Montréal, Québec.

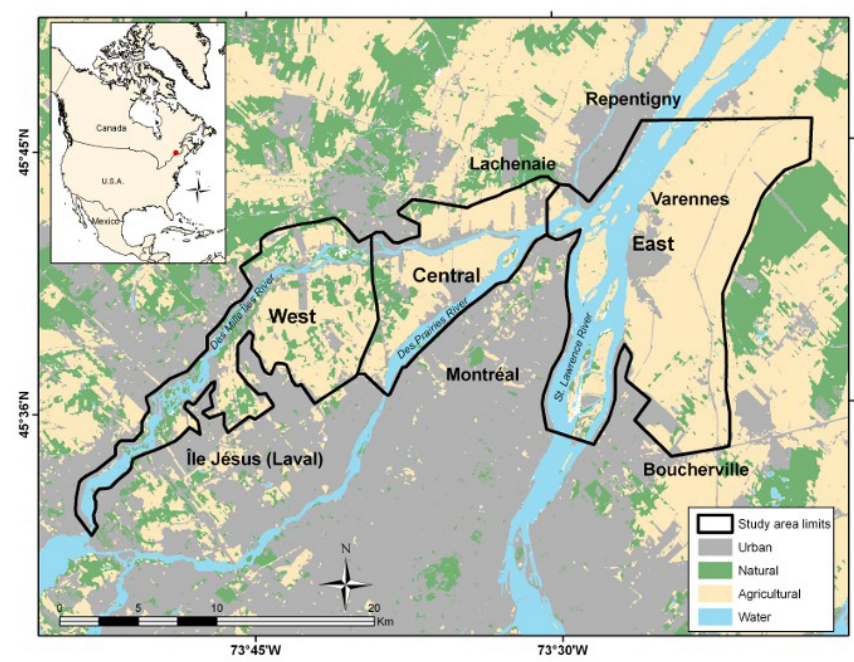

The central zone $\left(56 \mathrm{~km}^{2}\right)$ was located at the confluence of des Prairies and des Mille Îles rivers (Fig. 1). Boating activities are limited on these rivers because they can become shallow in late summer and fall. Agricultural lands dominated this zone, and fields were mainly cultivated to produce human food, i.e., sweet corn and vegetables. Hunting was allowed on the island of Montréal along the south shore of des Prairies River and in agricultural lands within the municipality of Lachenaie. This represented $12 \mathrm{~km}^{2}$ or $21 \%$ of the zone. The early and regular seasons occurred at the same time as in the east zone. Firearm discharge was prohibited by municipal bylaws elsewhere, including the entire Île Jésus in Laval.

The west zone $\left(72 \mathrm{~km}^{2}\right)$ was characterized by urban development with high human density and no hunting throughout the area. Many islands that constituted natural 
habitats dotted des Mille Îles River that flows through the area. Boating activities are limited to canoes and kayaks on this section of the river. Agricultural lands were concentrated on Île Jésus and in the most northerly portions of the zone.

Cold temperatures and freeze-up of water bodies in winter prevent the geese from staying all year round, and most of them winter in northeastern United States (Pilotte 2012). The geese arrive in the Varennes area at the end of March but their departure date was unknown. In addition, molt migrants from southern resident populations join the breeding flocks during the summer. They arrive during the first week of June and their departure date was, and still is, also unknown (Giroux et al. 2001). Other molt migrants pass through the area in June and continue to more northern sites, up to the Ungava Peninsula (J. Rodrigue, personal observation). During the fall, a portion of Canada Geese (Branta canadensis interior) that breed in Nunavik stage in southern Québec along with returning molt migrant Canada Geese (Malecki et al. 2001).

\section{Marking and tracking geese}

In early July 2003 and 2004, we captured prefledged juveniles and molting adults using corral traps. We put conventional alphanumeric plastic neck collars on a sample of adult females that had a brood patch. In spring 2004, we searched the four Varennes Islands (111.5 ha) for goose nests. Using a scoop net or a bow-net trap, we captured a sample of nesting females and equipped them with radio transmitters affixed to neck collars, total weight of $56 \pm 0.8 \mathrm{~g}$, which represented $<1.5 \%$ of their body weight (Demers et al. 2003). Nests were monitored until hatch to determine success and brood size of each marked female. Hatching juveniles were also marked with numbered web tags. Because we did not succeed in deploying all radios during the nesting period, we replaced conventional collars of females that were caught during the July banding drives by radio collars. Females that were caught in different drives than their web-tagged juveniles were assumed to have abandoned their young (Doiron 2006). Similarly, if a marked female was caught without any of the young that were marked in her nest, then it was assumed that she had lost her brood.

Starting in mid-July, when the geese were still molting, we located the radio-marked geese every day by telemetry using a Yagi antenna mounted on a vehicle or in a boat. When geese started to disperse, we searched each zone twice a week. Survey effort among zones was balanced between morning and afternoon periods. Tracking ended when the last radiotagged goose left the area. Radio-collared geese were assigned to a zone on a weekly basis. Whenever a bird was located in two zones during the same week, we associated it to the zone where it had not been observed the previous week to maximize information about movements. Residence time of each radiocollared goose during the hunting season was the number of days that elapsed between the opening of the special hunting season and the date of the last location in the study area.

Radio-tagged geese were located by triangulation or visual contact, and the locations were noted on 1:20,000 topographical maps. For each location, we recorded habitat according to three broad categories. Natural habitats were mainly riversides and islands that have not been modified by humans. Urban habitats included parks, golf courses, manmade ponds, and riversides that had been transformed by human activities. Finally, agricultural habitats included fields of different crops. We also noted whether the geese were located in areas where hunting or firearm discharge was allowed or not.

During the surveys conducted along roads throughout each zone, we searched for neck-collared females with a spotting scope (25-60 x) in all flocks regardless of the presence of radiotagged females. We recorded the number of individuals in each flock and computed the sum in goose-days for each week and zone. Finally, groups of hunters spotted during the surveys were recorded, summed for the whole season, and standardized by the number of days with surveys in each zone.

\section{Statistical analyses}

Survival and movement probabilities of collared geese were estimated using multistate capture-recapture models with program MARK, version 4.1 (Brownie et al. 1993, White and Burnham 1999). For multistate models, capture histories include both encounters and locations, i.e., state. In this study, the first capture consisted of observations of neck-collared geese during the molting period, and subsequent captures were the observations made during the following periods. Maximum likelihood estimates were obtained for $p_{t}^{r}=$ the probability that an individual was detected in zone $r$ at time $t$ given that the individual was alive, $\phi_{t}^{r}=$ the probability that an individual alive in zone $r$ at time $t$ survived and did not permanently emigrate from the study area until $t+1$, and $\psi^{r s}{ }_{t}$ $=$ the probability that an individual in zone $r$ at time $t$ be in zone $s$ at time $t+1$ given that the individual survived until $t+1$. We assumed that movement probabilities between $t$ and $t+1$ followed a first-order Markovian process, i.e., they only depended on the zone the individual was in at time $t$.

To minimize the number of parameters to be included in the models, we grouped recaptures into eight 3 -week periods. July 24 was set as the end of the molting period (M) based on the hatching date of the first nest and a 70-day fledging period (Hanson 1965). Two postmolting periods (PM1 and PM2) were set before the beginning of the special hunting season (SS) that spanned between 6 and 24 September. The regular hunting season opened on 25 September and four 3-week periods were established (RS1, RS2, RS3, and RS4). A bird seen in more than one zone for a given period was associated 
to the zone where it was most often encountered. When ties occurred, the bird was associated to the zone where it had not been encountered during the previous period to maximize information about movements. For the radio-marked birds, we used all locations during each three-week period and not the weekly assignments described above. We considered the probability of collar loss to be null during the study because of its short duration.

The most general model including $\phi, \mathrm{p}$, and $\psi$ as function of time $(t=7)$, zone $(z=3)$ and collar types $(c=2)$ was coded $\phi_{z^{*} t^{*} c}, p_{z^{*} t^{*} c}$, and $\psi_{z^{*} t^{*}}$, respectively. Geese tagged with conventional and radio collars were coded distinctively giving full encounter probability $\left(p_{t}^{r}=1\right)$ for radio-collared birds. To reduce the number of parameters, we tested models without group, i.e., collar type, constraints on $\phi$ and $\psi$ and models in which $p$ was function or not of $t$ and/or $z$. Our main interest was to investigate the effect of hunting on $\phi$ and $\psi$ using models that had biological significance. We tested different models using constraints relevant to the hunting regulations that changed among periods and zones. Goodness-of-fit tests were calculated using the program U-Care, 2.02 (Lebreton and Pradel 2003), which does not separate multistate tests but gives associated statistic values. We used the Akaike's Information Criterion (AIC $)_{c}$ to select the best approximating model (Burnham and Anderson 1998). We also used $\mathrm{AIC}_{c}$ weight $\left(\mathrm{AIC}_{c} \omega\right)$, which represents the weight of evidence in support of each model in the candidate set given the data.

We used compositional analyses to investigate how habitat use by radio-collared geese was affected by hunting (Aebischer et al. 1993). Availability was defined as the proportion of each habitat (natural, urban, and agricultural) within the entire study area. This was established from a digitized Landsat thematic map (TM, 30-m pixel) using ArcMap 9.1. We excluded forests from natural habitat and hardscape from the urban habitat because geese do not use these habitats. We also calculated the areas where hunting was allowed and prohibited within the natural and agricultural habitats, hunting being always prohibited in urban habitats. Habitat use was defined as the proportion of radio locations in each habitat for each individual. To satisfy unit-sum constraint and independency conditions, the sampling unit was the log-ratio of the proportion of locations of each individual (Aebischer et al. 1993).

We first tested whether habitat use differed significantly from random use before and during the hunting season. For each period, we ranked habitats from the most to the least exploited by geese and tested the significance of the associated Wilk's lambda $(\lambda)$ by randomization as recommended by Aebischer et al. (1993). We then used a MANOVA to investigate whether habitat use by radio-collared geese changed after the opening of the hunting season. Our second objective was to detect habitat preference during the hunting season by considering five habitat categories, i.e., natural with and without hunting, agricultural with and without hunting, and urban without hunting, in a compositional analysis. We also used randomization tests to determine the significant differences between ranks of the habitats used by geese. We used a paired $t$-test to compare the percentage of locations of individuals in hunted areas between the natural and agricultural habitats to evaluate whether geese were more susceptible to encounter hunters when using one of these habitats. Finally, a compositional analysis was used to compare habitat use by females that attended a brood and those that either abandoned or lost their brood during rearing. A Student $t$-test was also used to compare the percentage of locations in areas where hunting was prohibited between attending and nonattending females. All compositional analyses and randomization tests were performed with a modified SAS program written by Ott and Hovey (1997). Angular transformations were applied to percentage data. Means are presented $\pm 1 \mathrm{SE}$.

\section{RESULTS}

In 2003 and 2004, we banded 288 and 544 molting adults and fitted 91 and 124 females with conventional collars, respectively. We observed 150 females during the fall 2004 for a total of 1727 locations or $13.3 \pm 0.5$ per female (range: 1-36).

In 2004, we found 134 nests on the Varennes Islands and captured 19 females that we fitted with a radio collar. All hatched their nests successfully except two birds. Four females left the study area before molting (6-12 June). Three came back during the fall and one was shot in Massachusetts in November. These females had either lost their nests or abandoned their young during the brood-rearing period and this was confirmed by the recapture of at least one of their young during the July banding drives. We also replaced conventional collars of six females with radio collars during the banding drives. These females had been previously located on a nest, successful in hatching eggs, and had been regularly observed during the brood rearing and molting periods. Among the 21 radio-collared females that molted in the area, 1 had its nest preyed upon, 12 reared $\geq 1$ young, and 8 abandoned or lost their brood. A total of 1044 locations were obtained including 508 visual contacts (49\%) with an average of $47.1 \pm 1.5$ locations per female (range: $29-58$ ) and a mean interval of 3.3 days between each location.

We recorded seven times more hunters' parties in the east $(0.34 /$ day $)$ than in the central zone (0.05/day), and no hunter was observed in the west zone, as expected. Although we did not distinguish between those that were hunting geese and ducks, most waterfowl hunters in southern Québec will shoot at geese if they have the opportunity. The difference reflects the size of the area where hunting was allowed, which was 16 times larger in the east than in the central zone. The density of hunters' parties in the hunting areas was therefore greater 
Table 1. Chronology of hatching, departure from the east zone of the study area, and departure for the fall migration of radiocollared Canada Geese (Branta canadensis maxima) marked near Montréal, Québec, 2004.

\begin{tabular}{lccc}
\hline \hline Event & N females & Median date & Range \\
\hline Hatching & 23 & 20 May & 11 May - 12 June \\
Departure from the east zone & 21 & 16 August & 7 August - 11 September \\
Migration departure & 23 & 3 December & 9 October - 19 December \\
\hline
\end{tabular}

in the central than in the east zone ( 0.043 vs. 0.018 party/ day $/ 10 \mathrm{~km}^{2}$ ). However, when the entire zone is considered, which better reflects how safe a zone is, we found a greater density in the east than in the central zone (0.018 vs. 0.009 party/day $/ 10 \mathrm{~km}^{2}$ ). Moreover, 7 birds banded in 2003-2004 were recovered during the special early season within the study area, and 33 during the regular season. Most had been shot in the east zone (92.5\%). Hunting was restricted to agricultural lands during the early season although parties were predominantly observed along the shorelines of the rivers, natural habitats, in the east and central zones during the regular season (M. Beaumont, personal observation).

\section{Distribution and migration chronology}

During the molt and at the beginning of the postmolt periods, Canada Geese were concentrated in the east zone (Fig. 2A). This included the local birds that bred at Varennes and the molt migrants that arrived during the summer. All the radiocollared geese were located in this zone (Fig. 2B). Their numbers decreased rapidly by mid-August when the birds moved toward the central and west zones. This occurred when the juveniles were approximately three months old, well before the opening of the special hunting season in early September (Table 1).

Concomitant to this shift toward the west and central zones, arrival of B. c. interior and B. c. maxima from northern Québec increased the total number of birds in these two zones (Fig. 2A). The regular hunting season began at this time, and the maximum number of birds was recorded about three weeks later. Very few geese used the east zone during the hunting period compared to numbers observed in the central and west zones. Finally, a greater number of geese, including radiotagged birds, used the west rather than the central zone during the second half of the hunting season (RS3 and RS4). Only one radio-tagged goose was shot during the study, and this occurred during RS1 in the east zone. This goose had previously spent the PM1, PM2, and SS periods in the central zone.

Departure from the east zone spanned over one month, which was much shorter than the departures for migration that extended from early October to mid-December (Table 1). The radio-tagged geese were not located further south in Quebec during sporadic ground tracking throughout the area. Residence time during the hunting season lasts on average 88 days, which represents $82 \%$ of the duration of the whole hunting season (107 days).

Fig. 2. A) Number of Canada Geese (Branta canadensis maxima) counted per day and B) number of radio-collared geese located on a weekly basis in the west, central, and east zones near Montréal, Québec, 2004. See the Methods section for description of the periods.

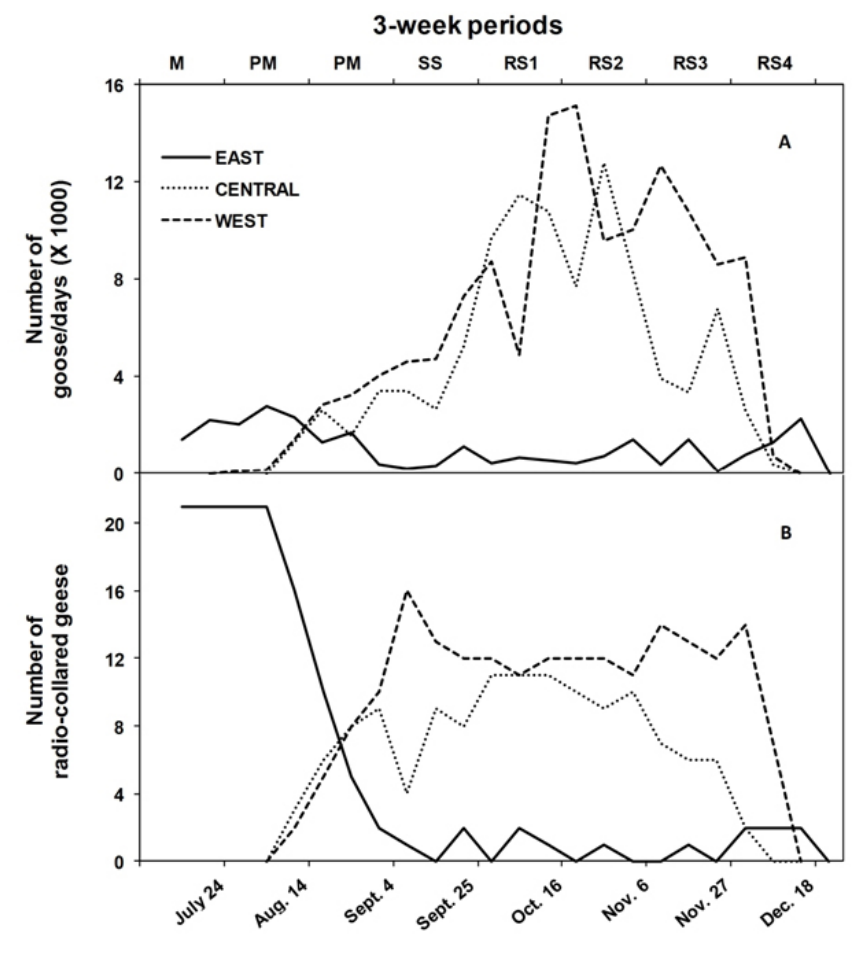

\section{Movements}

Pooling data on radio and conventional collars into 3-week periods resulted in 1026 locations, including 370, 357, and 299 in the east, central, and west zones, respectively. Multiple locations in different zones during a given period were limited to 8 and $15 \%$ of the locations for the radio-collared birds and the conventional collared geese, respectively. We are therefore confident that the assignments to a zone based on the greatest number of locations had little impact on our estimate of the use of each zone. 
Table 2. Model selection of regional movements of radio-marked and neck-collared Canada Geese (Branta canadensis maxima) near Montréal, Québec, 2004. $\triangle \mathrm{AICc}$, AICc $\omega$, and number of parameters $(\mathrm{K})$ of the multistate models are presented. The minimum AICc $=2328.839$ for the top-ranked model.

\begin{tabular}{|c|c|c|c|c|}
\hline$\underline{\text { Model } \dagger}$ & $\Delta \mathrm{AIC}_{c}$ & $\mathrm{AIC}_{c} \omega$ & $K$ & Deviance \\
\hline$\phi_{z^{*} t h} p_{t^{*} c} \psi_{z h^{*} t}$ & 0 & 0.56 & 54 & 685.71 \\
\hline$\phi_{z h^{*} t h} p_{t^{*} c} \psi_{z h^{*} t}$ & 0.49 & 0.44 & 52 & 690.69 \\
\hline$\phi_{z^{*} t} p_{t^{*} c} \psi_{z^{*} t}$ & 15.87 & 0 & 74 & 655.56 \\
\hline$\phi_{z^{*} t} p_{c} \psi_{z^{*} t}$ & 34.04 & 0 & 64 & 696.99 \\
\hline$\phi_{z} p_{t^{*} c} \psi_{z^{* t}}$ & 40.46 & 0 & 59 & 714.86 \\
\hline$\phi_{z * t} p_{z *^{*} *_{c}} \psi_{z * t}$ & 68.17 & 0 & 102 & 639.78 \\
\hline$\phi_{7 * *_{c}} p_{7 *_{t} *_{c}} \psi_{7 *_{*} *_{c}}$ & 172.00 & 0 & 162 & 581.48 \\
\hline
\end{tabular}

$†$ Model notation: $\phi=$ apparent survival; $p=$ detection probability; $\psi=$ movement probability; $z=$ zone (east, central, west); $t=$ time; $c=$ collar type; $h$ refers to models where $\phi$ or $\psi$ is time or spatial dependant in relation to hunting (See Results).

The general model fitted the data well $\left(\chi^{2}{ }_{102}=89.3 ; P>0.05\right)$. The two best models indicated that detection probability $(p)$ was time and group dependent although apparent survival probability $(\phi)$ and movement probability $(\psi)$ were related to hunting regulations (Table 2). Time constraints on $\phi$ indicated different survival probability after the opening of the hunting season $\left(\phi_{z h}: \phi_{1-2-3}^{r} \neq \phi_{4-5-6-7}^{r}\right)$ whereas a weak preference was shown for the model with full zone constraint on $\phi\left(\phi_{t}: \phi^{\text {east }}{ }_{t} \neq\right.$ $\left.\phi^{\text {central }}{ }_{t} \neq \phi^{\text {west }}\right)$ compared to one with hunting zone constraint on $\phi\left(\phi_{t h}: \phi^{\text {east }} \neq \phi_{t}^{\text {central-west }}\right)$. This last model estimated that $\phi$ for the east zone was $98.5 \%$ ( $\mathrm{SE}=0.01$ ) before the hunting season and $64.5 \%(\mathrm{SE}=0.16)$ during the hunting season, and $\phi$ for the central and the west zone together was $99.9 \%$ (SE = $0.01)$ and $96.1 \%(\mathrm{SE}=0.01)$ before and during the hunting season, respectively.

The best model suggested that constraint on $\psi$ because of hunting regulations implied only movements toward the east zone and suggested that $\psi$ was constant throughout the study until the last period $\left(\psi_{z h}: \psi_{1-2-3-4-5-6} \neq \psi_{7}\right.$ for $\psi^{\text {central } \rightarrow \text { east }}$ and $\left.\psi^{\text {west } \rightarrow \text { east }}\right)$ whereas no constraint on other movements was selected. Estimates of $\psi$ indicated increasing movements to the central and west zones before the opening of the regular hunting season (Fig. 3A). Thereafter, $\psi$ remained low except for a small increase during RS3 indicating some movements from the central to the west zone. When the opposite transitions were considered, movements from the west to the central zone occurred at the beginning of the hunting season. Movements toward the east zone were negligible during the whole period except during RS4 when some geese returned to their molting sites before departing for migration (Fig. 3B).

\section{Habitat use}

Radio-collared geese were predominantly located in natural habitats $(75.4 \pm 2.6 \%)$, followed by urban $(14.4 \pm 2.7 \%)$, and agricultural habitats $(10.3 \pm 0.8 \%)$. These habitats represented 49,49 , and $2 \%$ of the study area.
Fig. 3. Estimates ( $\pm 1 \mathrm{SE})$ of movement probability $(\psi)$ of radio-marked and neck-collared Canada Geese (Branta canadensis maxima) near Montréal, Québec during eight 3week periods in 2004 along A) a decreasing and B) increasing hunting pressure gradient. Estimates are derived from the best model selected with AIC. See the Methods section for description of the periods.

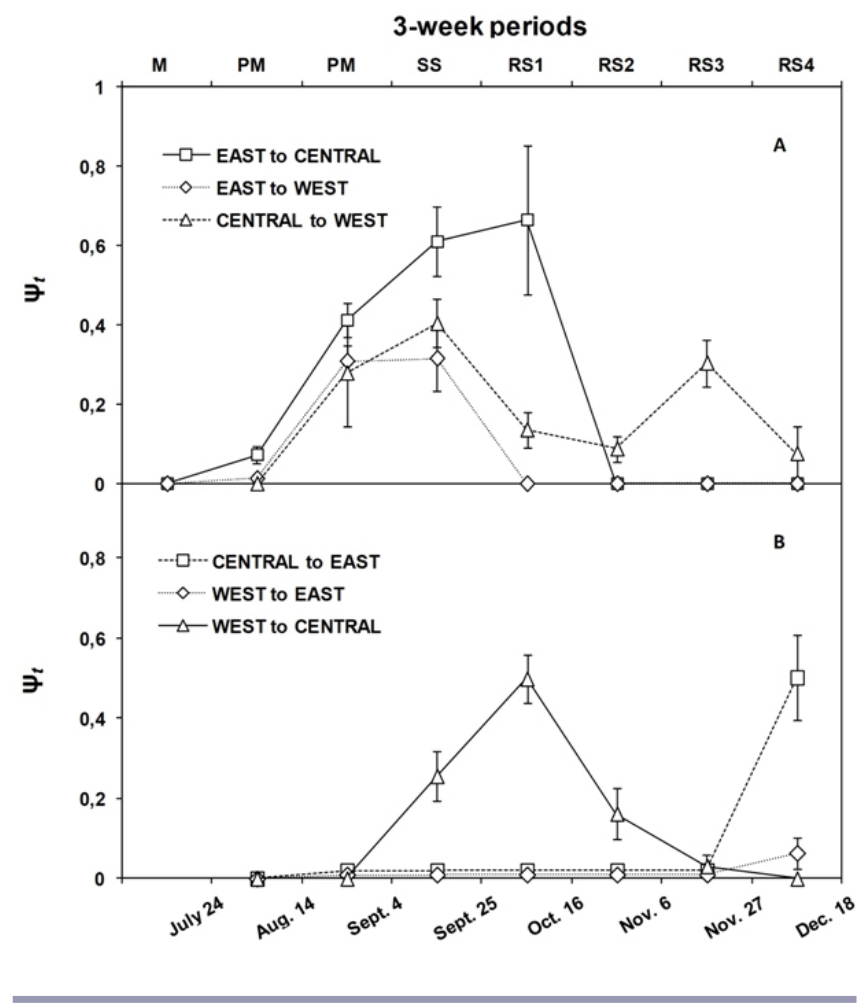


Geese using natural habitats were observed resting on des Mille Îles and des Prairies rivers and were often seen feeding in shallow water dominated by submerged vegetation along the shoreline or around the numerous islands. Urban habitats used by geese included lawns on private properties and city parks located along riversides, corporate managed landscapes surrounding industrial plants, and golf courses. In agricultural habitats, geese concentrated their feeding on spilled grains in stubble and plowed cornfields or small grain cereals. Harvest of cornfields in the central zone, sweet corn for human use, started in mid-August and was completed by late September. In the east zone, harvest of corn for grain started in late September and ended in December.

Compositional analysis showed a significant departure from random use of habitats during the fall both before $(\mathrm{n}=21$; Wilk's $\lambda=0.332$; randomized $P<0.001$ ) and during the hunting period ( $\mathrm{n}=24$; Wilk's $\lambda=0.353$; randomized $P<$ 0.001 ). Natural and urban habitats were both preferred over agricultural lands during the two periods. However, habitat use by geese changed slightly after the opening of the hunting season with geese spending more time in agricultural habitats $(4.7$ vs. $15.0 \%)$ and less in urban habitats (20.9 vs. $9.2 \%$; MANOVA, $F_{2,38}=5.49 ; P=0.003$ ). Concomitantly with the opening of the hunting season, cornfields were progressively harvested but most were ploughed within one to two days.

During the hunting season, radio-collared geese were located mainly in areas where hunting was prohibited $(73.2 \% \pm 6.2 \%)$. Significant departure from a random use was observed $(\mathrm{n}=$ 24; Wilk's $\lambda=0.096$; randomized $P<0.001$; Fig 4A). Urban habitats and nonhunting areas in natural habitats were the most preferred, and agricultural lands and areas accessible to hunters in natural habitats were the least preferred. Radiotagged geese were located relatively more often in a hunting area when using agricultural $(40.6 \pm 8.8 \%)$ rather than natural habitats $\left(26.6 \pm 6.3 \%, t_{23}=2.18 ; P=0.020\right)$. The relative areas open to hunting across the zones were similar in agricultural and natural habitats (63 and $65 \%$, respectively).

Geese that had attended a brood during the rearing period and that were still likely accompanied by juveniles after their molt did not use habitats randomly during the hunting season $(\mathrm{n}=$ 12; Wilk's $\lambda=0.053$; randomized $P<0.001$ ). They preferentially used no hunting areas in natural and urban habitats (Fig. 4B). Similarly, females that had abandoned or lost their brood also showed preferential use of no hunting areas in natural and urban habitats $(\mathrm{n}=12$; Wilk's $\lambda=0.116$; randomized $P<0.001$; Fig. 4C). Attending females were more often located in areas where hunting was prohibited than nonattending ones $\left(82.0 \pm 7.9 \%\right.$ vs. $64.8 \pm 9.2 \% ; t_{23}=2.54 ; P$ $=0.019)$.

Fig. 4. Mean ( $\pm 1 \mathrm{SE}) \%$ locations of radio-collared Canada Geese (Branta canadensis maxima) in different habitats during the hunting season near Montréal, Québec in 2004 for A) all radio-collared birds $(\mathrm{n}=24)$, B) attending females $(n=12)$, and C) nonattending females $(n=12)$. Habitat availability is the $\%$ of the surface area. Habitats are ranked from left to right in terms of selection and nonsignificant differences among habitats are indicated by a connected line ( $\mathrm{P}>0.05$, compositional analysis).
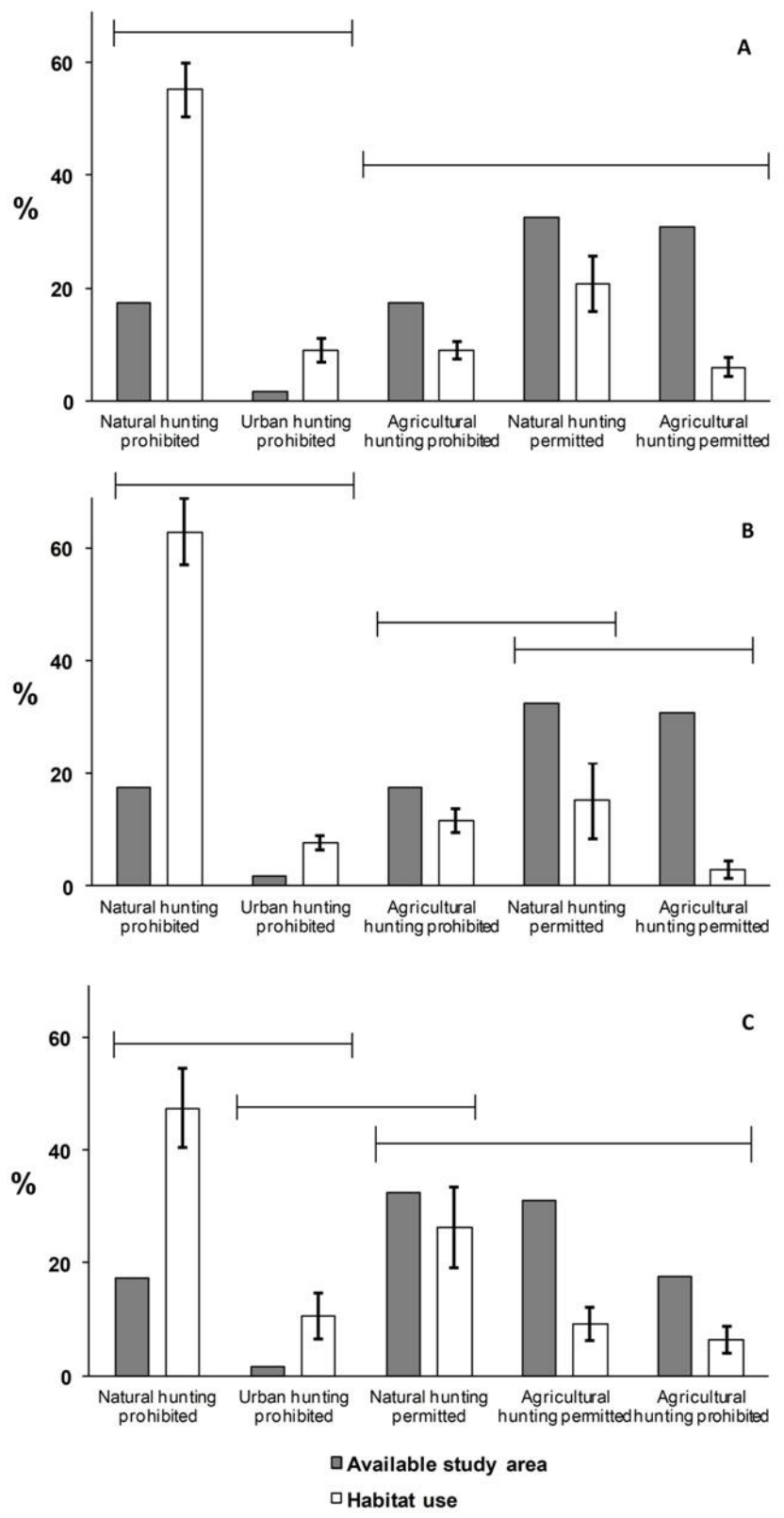

C 


\section{DISCUSSION}

We have shown that Canada Geese moved from their breeding and molting areas to other parts of the study area characterized by different hunting pressure, habitats, and disturbance levels. In Denmark, Madsen (1998) found that shooting was the most disturbing human activity that affected waterfowl distribution. After the implementation of a spring conservation hunt in Québec, Béchet et al. (2003) observed an increase of backward movements by migrating Snow Geese (Anser caerulescens atlanticus). This supports the idea that geese have the ability to assess the risk of being preyed upon or shot at by hunters, and that they can incorporate this information into their decision process (Lima and Dill 1990, Blumstein and Bouskila 1996). In our study, however, the shift from a high to a low hunting pressure area occurred several weeks before the opening of the hunting season indicating that individuals may use prior knowledge acquired from early experience and tradition (Béchet et al. 2003, McNamara et al. 2006, Valone 2006).

During the postbreeding period, females that reared their young and that were likely accompanied by juveniles spent more time in areas with no hunting than females that abandoned or lost their brood. This differential use of habitat directly benefits juveniles that have a higher survival rate than adults or yearlings (Pilotte 2012). Adults that did not attend juveniles were more often observed in areas open to hunting, and they may join the birds migrating from the north.

A nonmutually exclusive alternative explanation for the postbreeding movements of geese is the difference in resource availability among zones. Compared to the high hunting pressure area where conventional corn is harvested later in fall, sweet corn in the low hunting pressure area is collected in late summer providing some limited food resources before the opening of the hunting season. However, agricultural lands represented a small proportion of locations of the radiomarked birds. After the arrival of migrating birds from the north, few movements occurred, and geese stayed in areas where hunting pressure was low. Movements toward the area with a higher hunting pressure took place at the end of the hunting season, which coincided with improved feeding opportunities in stubble and plowed cornfields and with the presence of fewer hunters.

Disturbance may also affect the distribution of geese (Bélanger and Bédard 1989). There was much more disturbance in the east zone, which included a large section of the SaintLawrence River, than in the other zones where the rivers are much shallower. The Varennes area is characterized by an intense aquatic activity including recreational boating, kite boarding, windsurfing, and sport fishing that occurs especially in July and August. This may have prompted families with fledged juveniles to leave the area for more quiet sites along des Prairies and des Mille Îles rivers.
Avoiding areas with a predation risk, i.e., encounters with hunters, might have consequences on individual foraging opportunities. Several goose species feed on spilled grains, which may have a significant impact on their energy intake and consequently on population dynamics (Alisauskas et al. 1988, Hill and Frederick 1997, Gauthier et al. 2005). During our study, geese were more likely to be in contact with hunters when using agricultural rather than natural habitats. They were therefore more often observed feeding in marshes and shallow waters that may be less profitable than the agricultural lands. However, temperate nesting Canada Geese may not require a high rate of energy intake at this stage of their annual cycle. These large birds may be able to maintain body reserves during a long staging period. Moreover, the distance to the wintering grounds in northeastern United States is relatively short $(\approx 250-400 \mathrm{~km})$ and contrary to the prenuptial period, energy reserves may not need to be maintained at the maximum level during winter (Witter and Cuthill 1993). Although we did not track geese at night, we have no indication that they were feeding in fields at nighttime. This is supported by the fact that only 2 out of 83 locations obtained before sunrise or after sunset were in agricultural lands. Moreover, local hunters never reported geese in the fields when they set up their decoys a few hours before sunrise (F. St-Pierre, personal communication).

During the postbreeding period, resident Canada Geese use urban habitats because they can find undisturbed feeding sites (Conover and Kania 1991). Nuisance problems in southern Québec are currently limited and do not yet warrant extensive scaring programs (J. Rodrigue, unpublished data). However, the preferential use of this habitat might generate increased conflicts with humans. This is especially relevant when considering that the population is continuously increasing and expanding its range along the Saint-Lawrence River (J.-F. Giroux, unpublished data).

The management of temperate-nesting Canada Geese often relies upon reducing reproductive output, e.g., nest destruction, egg oiling. This may be effective in the northeastern states where a significant proportion of treated birds will undertake a molt migration, thus temporarily reducing local problems. However, these birds will often fly north, then increasing local populations as in southern Québec or in subarctic areas with a potential for competition with the migratory subspecies (Luukkonen et al. 2008). On the other hand, it has been shown that a reduction in adult survival is the most efficient measure to reduce population growth of geese and other species (Gauthier and Brault 1998, Hoekman et al. 2002). It is much easier to act when populations are starting to increase than when they reach their maximum growth rate.

Sport harvest can sometimes be efficient in controlling populations when specific regulations are established at a 
regional scale (Bregnballe et al. 2004). We have shown that the residence time of geese in the study area extended until late fall, which should provide opportunities for some harvest. However, urban sprawl has affected hunting activities in suburbs, which currently limits the use of hunting as a management measure. Our results clearly show that Canada Geese leave the areas where hunting can take place well before the opening of the season. Under the prevailing regulations, the potential role of hunting to manage the increasing breeding population of Canada Geese in southern Québec is limited. Innovative regulations should thus be implemented to liberalize firearm discharge in delimited areas and during restricted periods to increase the harvest of the local geese and the molt migrants. In Massachusetts, for instance, a high harvest rate was achieved during special hunting seasons in traditional sites as well as in atypical sites such as golf courses (Heusmann 1999). In Québec, hunters' participation during the special early season is still limited because only $9 \%$ of the total harvest of locally breeding geese occurred during this period (Pilotte 2012). More encouragement should thus be provided by wildlife agencies to promote this activity.

Responses to this article can be read online at:

http://www.ace-eco.org/issues/responses.php/570

\section{Acknowledgments:}

This study received financial support from Environment Canada and from a NSERC Discovery Research Grant to JFG. We acknowledge the contribution of many volunteers who helped with the banding operations and especially the technical assistance of F. St-Pierre. M. Patenaude-Monette and M. Benoit helped to produce the map. M. Doiron, A. Pannetier Lebeuf, C. Pilotte, E. T. Reed, P. Drapeau, and two anonymous reviewers commented on an earlier version of the manuscript.

\section{LITERATURE CITED}

Aebischer, N. J., P. A. Robertson, and R. E. Kenward. 1993. Compositional analysis of habitat use from animal radiotracking data. Ecology 74:1313-1325.

Alisauskas, R. T., C. D. Ankney, and E. E. Klaas. 1988. Winter diets and nutrition of midcontinental Lesser Snow Geese. Journal of Wildlife Management 52:403-414. http://dx.doi. org/10.2307/3801581

Ankney, C. D. 1996. An embarrassment of riches: too many geese. Journal of Wildlife Management 60:217-223. http://dx. doi.org/10.2307/3802219
Balkcom, G. D. 2010. Demographic parameters of rural and urban adult resident Canada Geese in Georgia. Journal of Wildlife Management 74:120-123. http://dx.doi.org/10.2193/2009-007

Bélanger, L., and J. Bédard. 1989. Responses of staging Greater Snow Geese to human disturbance. Journal of Wildlife Management 53:713-719. http://dx.doi.org/10.2307/3809202

Béchet, A., J.-F. Giroux, G. Gauthier, J. D. Nichols, and J. E. Hines. 2003. Spring hunting changes the regional movements of migrating Greater Snow Geese. Journal of Applied Ecology 40:553-564. http://dx.doi.org/10.1046/j.1365-2664.2003.00812. $\underline{\mathrm{x}}$

Blumstein, D. T., and A. Bouskila. 1996. Assessment and decision making in animals: a mechanistic model underlying behavioural flexibility can prevent ambiguity. Oikos 77:569-576. http://dx.doi.org/10.2307/3545948

Bregnballe, T., J. Madsen, and P. A. F. Rasmussen. 2004. Effects of temporal and spatial hunting control in waterbird reserves. Biological Conservation 119:93-104. http://dx.doi. org/10.1016/j.biocon.2003.10.025

Brownie, C., J. E. Hines, J. D. Nichols, K. H. Pollock, and J. B. Hestbeck. 1993. Capture-recapture studies for multiple strata including non-Markovian transitions. Biometrics 49:1173-1187. http://dx.doi.org/10.2307/2532259

Burnham, K. P., and D. R. Anderson. 1998. Model selection and inference: a practical information-theoretic approach. Springer, New York, New York, USA.

Conover, M. R., and G. G. Chasko. 1985. Nuisance Canada Goose problems in the eastern United States. Wildlife Society Bulletin 13:228-233.

Conover, M. R., and G. S. Kania. 1991. Characteristics of feeding sites used by urban-suburban flocks of Canada Geese in Connecticut. Wildlife Society Bulletin 19:36-38.

Demers, F., J.-F. Giroux, G. Gauthier, and J. Bêty. 2003. Effects of collar-attached transmitters on behaviour, pair bond and breeding success of Snow Geese Anser caerulescens atlanticus. Wildlife Biology 9:161-170. [online] URL: http:// www.uqar.ca/files/biodiversite-nordique/Demersetal2003W$\underline{\text { ildlifeBiology.pdf }}$

Doiron, M. 2006. Élevage et croissance des jeunes chez la Bernache du Canada résidente dans le sud du Québec. Thesis. Université du Québec à Montréal, Montréal, Québec, Canada.

Frederick, R. B., and E. E. Klaas. 1982. Resource use and behavior of migrating Snow Geese. Journal of Wildlife Management 46:601-614. http://dx.doi.org/10.2307/3808550

Gauthier, G., J.-F. Giroux, A. Reed, A. Béchet, and L. Bélanger. 2005. Interactions between land use, habitat use, 
and population increase in Greater Snow Geese: what are the consequences for natural wetlands? Global Change Biology 11:856-868. http://dx.doi.org/10.1111/j.1365-2486.2005.00944. $\underline{\mathrm{x}}$

Gauthier, G., and S. Brault. 1998. Population model of the Greater Snow Goose: projected impacts of reduction in survival on population growth rate. Pages 65-80 in B. D. J. Batt, editor. The Greater Snow Goose. Report of the Arctic goose habitat working group. Arctic Goose joint venture special publication, U.S. Fish and Wildlife Service, Washington, D.C., USA and Canadian Wildlife Service, Ottawa, Ontario, Canada.

Giroux, J.-F., J. Lefebvre, L. Bélanger, J. Rodrigue, and S. Lapointe. 2001. Establishment of a breeding population of Canada Geese in southern Québec. Canadian Field-Naturalist 115:75-81.

Hanson, H. C. 1965. The giant Canada Goose. Southern Illinois University Press, Carbondale, Illinois, USA.

Heusmann, H. W. 1999. Special hunting seasons and resident Canada Goose populations. Wildlife Society Bulletin 27:456-464.

Hill, M. R. J., and R. B. Frederick. 1997. Winter movements and habitat use by Greater Snow Geese. Journal of Wildlife Management 61:1213-1221. http://dx.doi.org/10.2307/3802119

Hindman, L. J., K. M. Dickson, W. F. Harvey, and J. R. Serie. 2004. Atlantic flyway Canada Geese: new perspectives in goose management. Pages 12-17 in T. J. Moser, R. D. Lien, K. C. VerCauterren, K. F. Abraham, D. E. Andersen, J. G. Bruggink, J. M. Coluccy, D. A. Graber, J. O. Leafloor, D. R. Luukkonen, and R. E. Trost, editors. Proceedings of the 2003 international Canada Goose symposium. International Canada Goose symposium, Madison, Wisconsin, USA.

Hoekman, S.T., L. S. Mills, D. W. Howerter, J. H. Devries, and I. J. Ball. 2002. Sensitivity analyses of the life cycle of midcontinent mallards. Journal of Wildlife Management 66:883-900. http://dx.doi.org/10.2307/3803153

Johnson, M. A. 1997. Management strategies to address the mid-continent Lesser Snow Goose overpopulation problem. Pages 101-111 in B. D. J. Batt, editor. Arctic ecosystem in peril: report of the Arctic goose habitat working group. U.S. Fish and Wildlife Service, Washington, D.C., USA and Canadian Wildlife Service, Ottawa, Ontario, Canada. [online] URL: http://www.fws.gov/migratorybirds/CurrentBirdIssues/ Management/arcgoose/partiv/partiv.pdf

Lebreton, J.-D., and R. Pradel. 2003. U-Care 2.02. Université de Montpellier, Montpellier, France.

Lima, S. L., and L. M. Dill. 1990. Behavioral decisions made under the risk of predation: a review and prospectus. Canadian
Journal of Zoology 68:619-640. http://dx.doi.org/10.1139/ z90-092

Luukkonen, D. R., H. H. Prince, and R. C. Mykut. 2008. Movements and survival of molt migrant Canada Geese from southern Michigan. Journal of Wildlife Management 72:449-462. http://dx.doi.org/10.2193/2007-029

Madsen, J. 1998. Experimental refuges for migratory waterfowl in Danish wetlands. I. Baseline assessment of the disturbance effects of recreational activities. Journal of Applied Ecology 35:386-397. http://dx.doi.org/10.1046/ j.1365-2664.1998.00314.x

Madsen, J., and A. D. Fox. 1995. Impacts of hunting disturbance on waterbirds - a review. Wildlife Biology 1:193-207.

Malecki, R. A., B. D. J. Batt, and S. E. Sheaffer. 2001. Spatial and temporal distribution of Atlantic population Canada Geese. Journal of Wildlife Management 65:242-247. http://dx. doi.org/10.2307/3802903

McNamara, J. M., R. F. Green, and O. Olsson. 2006. Bayes' theorem and its applications in animal behaviour. Oikos 112:243-251. http://dx.doi.org/10.1111/j.0030-1299.2006.14228. $\underline{\mathrm{x}}$

Ott, P., and F. Hovey. 1997. Compositional analysis, version 1.0. Illinois Natural History Survey, Champaign, Illinois, USA.

Pilotte, C. 2012. Survie annuelle des Bernaches du Canada (Branta canadensis maxima) établies dans le sud du Québec. Thesis. Université du Québec à Montréal, Montréal, Québec, Canada.

Stephens, D. W., and J. R. Krebs. 1986. Foraging theory. Princeton University Press, Princeton, New Jersey, USA.

U.S. Fish and Wildlife Service. 2010. Waterfowl population status, 2010. U.S. Department of the Interior, Washington, D. C., USA. [online] URL: http://www.fws.gov/migratorybirds/ NewReportsPublications/PopulationStatus/Waterfowl/ StatusReport2010_Final.pdf

Valone, T. J. 2006. Are animals capable of Bayesian updating? An empirical review. Oikos 112:252-259. http://dx.doi. org/10.1111/j.0030-1299.2006.13465.x

White, G. C., and K. P. Burnham. 1999. Program MARK: survival estimation from populations of marked animals. Bird Study 46:120-139. http://dx.doi.org/10.1080/00063659909477239

Witter, M. S., and I. C. Cuthill. 1993. The ecological costs of avian fat storage. Philosophical Transactions of the Royal Society of London, Series B 340:73-92. http://dx.doi. org/10.1098/rstb.1993.0050 